\title{
POTENTIAL SIGNIFICANCE OF BRADYKININ 2 RECEPTOR GENOTYPING IN KIDNEY TRANSPLANT RECIPIENTS
}

\author{
Katarina Danković1 , Nikola Stefanović ${ }^{1}$, Radmila Veličković-Radovanović1,2, \\ Branka Mitić1,2, Goran Paunović ${ }^{2}$, Mina Cvetković1,2, Tatjana Cvetković1,3
}

\begin{abstract}
Bradykinin (BK), a vasoactive peptide, is considered to exert the renoprotective and cardioprotective effects. Furthermore, most of its effects are mediated by the activation of BK type 2 receptor (B2R), whose level of expression is influenced by insertion/deletion (+9/-9) gene polymorphism. The aim of this study was to investigate the potential influence of B2R $+9 /-9$ gene polymorphism on kidney function and blood pressure in kidney transplant recipients (KTRs) within the first post-transplantation year. Secondary, the study analyzed the correlation between hypertensive status and graft function, with respect to the $B 2 R+9 /-9$ gene polymorphism.

The pharmacogenetic study included 95 KTRs with clinical and biochemical parameters evaluated in three time-points $\left(3^{\text {rd }}, 6^{\text {th }}, 12^{\text {th }}\right.$ month). The graft function was assessed using the estimated glomerular filtration rate (eGFR), while systolic (SBP), diastolic (DBP), and mean blood pressure (MAP) were used as parameters for the evaluation of blood pressure control.

The carriers of $-9 /-9$ genotype had more stable graft function compared to both, heterozygotes and homozygous for +9 allele, not only in the early (up to 6 months) but as well in the late post-transplantation period (beyond 6 months). Also, the $-9 /-9$ genotype carriers showed a tendency to significantly decrease MAP, SBP, and DBP in the observed period, whereby only in this patient group the significant association between hypertensive status and graft function was demonstrated.

In conclusion, genotyping of B2R $+9 /-9$ gene polymorphism alongside with biochemical and clinical parameters may identify patients with respect to the risk of more prompt decline of graft function.
\end{abstract}

Acta Medica Medianae 2021;60(1):19-27.

Key words: $B 2 R$ polymorphism, kidney transplantation, blood pressure, graft function, antihypertensive therapy

${ }^{1}$ University of Niš, Faculty of Medicine, Niš, Serbia

${ }^{2}$ Clinical Center Niš, Clinic of Nephrology, Niš, Serbia

${ }^{3}$ Clinical Center Niš, Center for Medical and Clinical

Biochemistry, Niš, Serbia

Contact: Nikola Stefanović

48 Dr Zoran Djindjić Blvd., 18000 Niš, Serbia

E-mail: nikola.stefanovic@medfak.ni.ac.rs

\section{Introduction}

Kidney transplantation (Tx) is the optimal treatment choice for patients with end-stage kidney disease. Still, besides the remarkable patient and graft survival rates in the first year after Tx, lack of improvement in long-term outcomes remains a problem of interest $(1,2)$. Kidney transplant recipients (KTRs) are considered to have chronic kidney disease, even immediately after Tx, whereas the incidence of cardiovascular morbidity and mortality is higher compared to the general population. Furthermore, some patients exert rapid and pronounced decline in kidney function, while others have stable graft function (3).

Therefore, it seems important to identify the components of the organism that can affect transplanted kidney in positive (renoprotective) or negative manner. Bradykinin (BK), a vasoactive peptide of the kinin group of proteins, has a central role in the kallikrein-kinin system (KKS) and participates in specific physiological and pathological conditions, such as inflammation and pain sensation, blood pressure regulation, glucose homeostasis, oxidative stress, regulation of renal blood flow, and water and sodium excretion. Tissue levels of BK are generally higher than circulating levels, with relatively high concentrations present in the kidney, heart, and aorta $(4,5,6)$. Some scientists suggest that kinins exert hemodynamic effects primarily in the heart and kidney, thus affecting the local redistribution of blood flow and perfusion within these organs (7). 
Bradykinin can bind to type 1 receptor (B1R), but most of its biological effects are mediated by the activation of BK type 2 receptor (BDKRB2, B2R) (8). The level of B2R expression is influenced by insertion/deletion (+9/-9) gene polymorphism present in exon 1 of the B2R gene. Studies demonstrated that the presence of 9 base pairs sequence $(+9 \mathrm{bp})$ rather than its absence (-9bp) is associated to lower gene transcriptional activity. It is supposed that the +9 allele carriers have an increased risk for developing diabetes mellitus and essential hypertension $(9,10)$. Considering the well-known renoprotective role of $\mathrm{BK}$, studying variations in the gene encoding B2R within KTRs can be of potential significance in clinical practice.

Interdependence between hypertension and adverse graft outcomes is one of the major characteristics of Tx. Namely, high and uncontrolled blood pressure is associated with a decline in graft function, increased risk of graft loss, and poor graft survival. Nevertheless, chronic allograft dysfunction, renal artery stenosis, recurrence of glomerulonephritis and diseased native kidneys may be the risk factors for the development of hypertension in KTRs $(11,12)$. Since activation of BK and its receptors is considered protective in cardiovascular and renal diseases, this study impregnated gene variation with these two entities, inseparable in KTRs.

The main goal of the study was to investigate whether the B2R +9/-9 gene polymorphism might have influenced the graft function and blood pressure or not, in the first year after Tx. Furthermore, the study analyzed the association between hypertensive status and graft function (expressed as estimated glomerular filtration rate, eGFR), with respect to the $B 2 R+9 /-9$ gene polymorphism.

\section{Patients and methods}

\section{Study population}

This single-center pharmacogenetic study was conducted at the Clinic of Nephrology, Clinical Center Niš, Serbia and at the Scientific Research Center for Biomedicine, Faculty of Medicine, University of Niš, Serbia. The genotyping analysis included 95 Caucasian patients who had transplantation surgery at the Clinical Center Niš and were monitored at the Clinic of Nephrology. The present study involved a period from 1 up to 12 months after $T x$, with biochemical and clinical parameters being evaluated in three time-points (third, sixth and twelfth month). The kidney transplant recipients met some exclusion criteria before they were enrolled into this study, and therefore we excluded patients who underwent Tx less than one year before, patients with any sign of graft failure demanding regular dialysis within the first post-transplantation year and patients on angiotensin-converting enzyme (ACE) inhibitors. Of patients enrolled into the study, 60 were men and 35 were women, mean age $39.23 \pm 10.70$ at the beginning of the study. The graft function was assessed using the value of eGFR, while systolic $(\mathrm{SBP})$, diastolic (DBP), and mean blood pressure
(MAP) were used as parameters for the evaluation of blood pressure control. Mean blood pressure was calculated as a composite sum of SBP and double value of DBP divided by 3 . The data used in the study were taken from the medical records of KTRs. The study was approved by the Ethics Committee of the Faculty of Medicine, University of Niš and fully informed written consent was obtained from each patient (No 12-6972-2/5 from 02.07.2018).

\section{Immunosuppressive protocol}

All patients started with an immunosuppressive protocol that besides tacrolimus (Tac) included intravenous methylprednisolone, with an initial dose of $0.5 \mathrm{~g} /$ day for 2 or 3 days, which was later switched to prednisone, initial dose of $1 \mathrm{mg} / \mathrm{kg} / \mathrm{day}$, mycophenolate mofetil, $1.5-2 \mathrm{~g} /$ day or mycophenolic acid, $1080-1440 \mathrm{mg} /$ day orally and $20 \mathrm{mg}$ monoclonal antibody basiliximab which was administered at the first and the fourth day after transplantation. The first oral Tac dose was administered on day 5 post-transplantation at $8.00 \mathrm{~h}$ before breakfast $(0.1 \mathrm{mg} / \mathrm{kg}$ or $0.2 \mathrm{mg} / \mathrm{kg})$. Afterward, Tac was administered twice daily $(08.00 \mathrm{~h}$ and $20.00 \mathrm{~h}$ ) or once daily $(08.00 \mathrm{~h})$ depending on the prescribed drug.

Besides standard immunosuppressive therapy, patients also received antihypertensive drugs: beta blockers (bisoprolol, metoprolol or carvedilol) and/or calcium channel blockers (amlodipine, lercanidipine, and nifedipine), and rarely methyldopa. For gastroprotection, patients used omeprazole, pantoprazole or ranitidine. The eGFR was calculated by The Modification of Diet in Renal Disease (MDRD) equation (13).

\section{Genotyping B2R polymorphism}

A fasting blood sample was taken from each patient during routine control at the Clinic. Genomic DNA was ex-tracted from the whole blood $(200 \mu \mathrm{L})$ with EDTA as an anticoagulant using Genomic DNA Purification Kit (Fermentas, Thermo Scientific, Lithuania), according to the manufacturer's instructions. In order to deter-mine $9 \mathrm{bp}$ insertion/deletion polymorphism within the B2R gene, a modified method described by Fischer et al. (14) was used.

In a total volume of $12.5 \mu \mathrm{L}$, each reaction mixture contained $6.25 \mu \mathrm{L}$ of KAPA2G Readymix (KAPA2G Readymix FastHotStart, KapaBiosystems, Boston, USA), which already contains Hot Start DNA polymerase, dNTPs, $\mathrm{MgCl}_{2}$ and stabilizers. In addition to the commercial mix, we added $0.25 \mu \mathrm{L}$ of forward and reverse primers (F: 5'-TCC AGC TCT GGC TTC TGG-3' and R: 5'-AGT CGC TCC CTG GTA CTG C-3'), concentration of $10 \mathrm{pmol} / \mu \mathrm{L}, 4.75 \mu \mathrm{L}$ of deionized water and $1 \mu \mathrm{L}$ of isolated DNA (average concentration $50 \mathrm{ng} / \mu \mathrm{L}$ ). For the amplification of PCR products, a program was followed: initial denaturation for $2 \mathrm{~min}$ at $95{ }^{\circ} \mathrm{C}$, followed with 35 cycles of denaturation for $29 \mathrm{sec}$ at $95^{\circ} \mathrm{C}$, annealing for $30 \mathrm{sec}$ at $60{ }^{\circ} \mathrm{C}$, elongation for $20 \mathrm{sec}$ at $72{ }^{\circ} \mathrm{C}$ with final elongation for $1 \mathrm{~min}$ at $72{ }^{\circ} \mathrm{C}$. Amplifica- 
tion products were detected on 3\% agarose gel. The length of an amplified product in the determination of -9 B2R allele was 80 bp and for +9 B2R allele 89 bp.

\section{Statistical analysis}

The distribution of genotypes for B2R polymorphism was assessed for deviation from HardyWeinberg equilibrium (HWE). A Student's t-test for independent samples (for normally distributed data) or Mann-Whitney $U$ test (not normally distributed data) was used to compare eGFR values between patients with blood pressure levels within or beyond target range in relation to B2R genotype. One-way ANOVA for independent samples (for a normal distribution of parameter values) or Kruskal-Wallis test (the normality in the distribution of parameter values was not satisfied) was performed to detect the significant differences in eGFR, SBP, DBP and MAP between and within the different genotypes. A Chisquare $\left(\chi^{2}\right)$ test was employed to compare the distribution of prescribed antihypertensive regimens between B2R genotypes. Statistical analyses were performed using SPSS statistical analysis software (version 20.0) at the significance level set at $\mathrm{p}<$ 0.05 .

\section{Results}

The characteristics of the study population are given in Table 1. Genotype frequencies did not deviate from HWE $(p>0.05)$ for tested B2R polymorphism: $\chi^{2}=0.90, p=0.34$.

Table 2 shows a comparison of eGFR values among different B2R genotypes as well as within genotypes in three time-points after Tx. The obtained results clearly pointed to enhanced and more stable graft function in carriers of both -9 alleles compared to both heterozygotes and $+9 /+9$ genotype carriers not only in the early (up to 6 months), but as well in the late post-transplantation period (beyond 6 months). On the other side, the eGFR values did not differ significantly within any genotype group during one-year follow-up period.

Considering the blood pressure parameters, we analyzed MAP, SBP, and DBP between and within B2R genotypes in three time-points after Tx (Table 3 ). The obtained results reported that the carriers of both -9 alleles showed a tendency to significantly decrease MAP, SBP, and DBP within the observed period. There was no statistical difference in examined parameters between genotypes during the entire study period, except for MAP at the $12^{\text {th }}$ month. However, the mean parameter values at the end of the first year indicated an obvious clinical divergence in controlling blood pressure between genotypes.

Table 1. Characteristics of the study population

\begin{tabular}{|c|c|c|c|}
\hline & $\begin{array}{l}3^{\text {rd }} \text { month post- } \\
\text { transplantation }\end{array}$ & $\begin{array}{l}6^{\text {th }} \text { month post- } \\
\text { transplantation }\end{array}$ & $\begin{array}{l}12^{\text {th }} \text { month post- } \\
\text { transplantation }\end{array}$ \\
\hline Sex (male/female) & \multicolumn{3}{|c|}{$60 / 35(63.2 \% / 36.8 \%)$} \\
\hline Tx type (LDT/DDT) & \multicolumn{3}{|c|}{$69 / 26(72.6 \% / 27.4 \%)$} \\
\hline Age (years)* & \multicolumn{3}{|c|}{$\begin{array}{c}39.23 \pm 10.70 \\
39(31-47)\end{array}$} \\
\hline $\begin{array}{c}\text { B2R genotype: } \\
-9 /-9 ;-9 /+9 ;+9 /+9\end{array}$ & \multicolumn{3}{|c|}{$15 / 51 / 29(15.8 \% / 53.7 \% / 30.5 \%)$} \\
\hline $\begin{array}{l}\text { B2R genotype: } \\
-9 \text { allele } /+9 \text { allele }\end{array}$ & \multicolumn{3}{|c|}{$42.63 \% / 57.37 \%$} \\
\hline Body mass (kg) & $\begin{array}{c}71.03 \pm 13.63 \\
70(60.75-78.50)\end{array}$ & $\begin{array}{l}71.43 \pm 13.84 \\
70.50(60-78)\end{array}$ & $\begin{array}{l}73.95 \pm 15.03 \\
71.70(65-81)\end{array}$ \\
\hline CRE ( $\mu \mathrm{mol} / \mathrm{L})$ & $\begin{array}{c}143.05 \pm 42.29 \\
137(113-166) \\
\end{array}$ & $\begin{array}{c}141.97 \pm 40.83 \\
136(115-156)\end{array}$ & $\begin{array}{c}136.11 \pm 44.50 \\
123(108.50-154.50)\end{array}$ \\
\hline $\begin{array}{c}\text { eGFR } \\
\left(\mathrm{mL} / \mathrm{min} / 1.73 \mathrm{~m}^{2}\right)\end{array}$ & $\begin{array}{c}46.66 \pm 12.70 \\
47.22(39.08-53.20)\end{array}$ & $\begin{array}{c}46.95 \pm 13.38 \\
45.50(38.63-55.03)\end{array}$ & $\begin{array}{c}50.80 \pm 17.29 \\
48.56(40.48-60.30)\end{array}$ \\
\hline MAP & $\begin{array}{c}96.72 \pm 8.47 \\
96.67(93.33-102.50)\end{array}$ & $\begin{array}{c}95.49 \pm 9.20 \\
95(91.67-100)\end{array}$ & $\begin{array}{c}95.71 \pm 8.64 \\
96.67(90-101.67)\end{array}$ \\
\hline SBP & $\begin{array}{c}128.69 \pm 12.92 \\
130(120-140)\end{array}$ & $\begin{array}{c}127.30 \pm 13.76 \\
130(120-130)\end{array}$ & $\begin{array}{c}127.69 \pm 11.86 \\
130(120-140)\end{array}$ \\
\hline DBP & $\begin{array}{c}80.73 \pm 7.53 \\
80(80-85) \\
\end{array}$ & $\begin{array}{c}79.58 \pm 8.02 \\
80(75-85) \\
\end{array}$ & $\begin{array}{c}79.71 \pm 8.41 \\
80(70-85) \\
\end{array}$ \\
\hline
\end{tabular}

Data are expressed as mean \pm standard deviation and median (IQR) or number and percentage. *age at the beginning of the study; LTD-living donor transplantation; DDT-deceased donor transplantation; CRE-serum creatinine concentration; eGFRestimated glomerular filtration rate; MAP-mean blood pressure; SBP-systolic blood pressure; DBP-diastolic blood pressure 
Table 2. eGFR in one-year period following Tx with respect to the B2R genotype

\begin{tabular}{|c|c|c|c|c|}
\hline $\begin{array}{c}\text { B2R } \\
\text { genotype }\end{array}$ & $\begin{array}{c}\text { eGFR at third month } \\
\text { post-transplantation } \\
\left(\mathrm{mL} / \mathrm{min} / 1.73 \mathrm{~m}^{2}\right)\end{array}$ & $\begin{array}{c}\text { eGFR at sixth month } \\
\text { post-transplantation } \\
\left(\mathrm{mL} / \mathrm{min} / 1.73 \mathrm{~m}^{2}\right) \\
\end{array}$ & $\begin{array}{c}\text { eGFR at twelfth month } \\
\text { post-transplantation } \\
\left(\mathrm{mL} / \mathrm{min} / 1.73 \mathrm{~m}^{2}\right) \\
\end{array}$ & p value \\
\hline$-9 /-9$ & $\begin{array}{c}55.71 \pm 14.77 \\
52.11(48.89-56.70)\end{array}$ & $\begin{array}{c}54.13 \pm 16.01 \\
47.90(45.38-61.34)\end{array}$ & $\begin{array}{c}62.06 \pm 19.59 \\
56.36(53.02-63.78)\end{array}$ & 0.285 \\
\hline$-9 /+9$ & $\begin{array}{c}43.73 \pm 11.55 \\
44.21(35.18-52.10)\end{array}$ & $\begin{array}{c}43.95 \pm 13.06 \\
44.88(35.49-52.68)\end{array}$ & $\begin{array}{c}49.06 \pm 18.32 \\
45.28(37.12-57.66)\end{array}$ & 0.140 \\
\hline$+9 /+9$ & $\begin{array}{c}46.83 \pm 11.45 \\
46(41.38-53.29)\end{array}$ & $\begin{array}{c}48.14 \pm 10.98 \\
47.24(41.56-57.30)\end{array}$ & $\begin{array}{c}48.68 \pm 12.17 \\
50.61(40.77-58.60)\end{array}$ & 0.830 \\
\hline p value & $0.005^{*}$ & $0.030 *$ & $0.042 *$ & \\
\hline
\end{tabular}

*significant difference; eGFR-estimated glomerular filtration rate

Table 3. Blood pressure parameters in one-year period following Tx with respect to the B2R genotype

\begin{tabular}{|c|c|c|c|c|}
\hline $\begin{array}{c}\text { B2R } \\
\text { genotype }\end{array}$ & $\begin{array}{c}\text { MAP at third month } \\
\text { post-transplantation } \\
(\mathrm{mmHg})\end{array}$ & $\begin{array}{c}\text { MAP at sixth month } \\
\text { post-transplantation } \\
(\mathrm{mmHg})\end{array}$ & $\begin{array}{c}\text { MAP at twelfth month } \\
\text { post-transplantation } \\
(\mathrm{mmHg})\end{array}$ & $\begin{array}{c}\mathbf{p} \\
\text { value }\end{array}$ \\
\hline$-9 /-9$ & $\begin{array}{c}99.89 \pm 8.05 \\
96.67(94.17-105) \\
\end{array}$ & $\begin{array}{c}99.17 \pm 5.84 \\
96.67(95-101.67) \\
\end{array}$ & $\begin{array}{c}89.33 \pm 10.16 \\
90(83.33-96.67)\end{array}$ & $0.005 *$ \\
\hline$-9 /+9$ & $\begin{array}{c}95.06 \pm 8.21 \\
93.33(90-100)\end{array}$ & $\begin{array}{c}93.91 \pm 9.90 \\
93.33(90-97.50)\end{array}$ & $\begin{array}{c}96.24 \pm 8.44 \\
96.67(90-103.33) \\
\end{array}$ & 0.480 \\
\hline$+9 /+9$ & $\begin{array}{c}97.78 \pm 8.73 \\
96.67(93.33-101.67)\end{array}$ & $\begin{array}{c}96.13 \pm 9.08 \\
95(93.33-101.67)\end{array}$ & $\begin{array}{c}97.36 \pm 7.46 \\
96.67(93.33-103.33)\end{array}$ & 0.757 \\
\hline p value & 0.116 & 0.097 & $0.036 *$ & \\
\hline $\begin{array}{c}\text { B2R } \\
\text { genotype }\end{array}$ & $\begin{array}{c}\text { SBP at third month } \\
\text { post-transplantation } \\
(\mathrm{mmHg}) \\
\end{array}$ & $\begin{array}{c}\text { SBP at sixth month } \\
\text { post-transplantation } \\
(\mathrm{mmHg}) \\
\end{array}$ & $\begin{array}{c}\text { SBP at twelfth month } \\
\text { post-transplantation } \\
(\mathrm{mmHg})\end{array}$ & $\begin{array}{c}\mathbf{p} \\
\text { value }\end{array}$ \\
\hline$-9 /-9$ & $\begin{array}{c}131.67 \pm 10.12 \\
130(122.50-140) \\
\end{array}$ & $\begin{array}{c}131.79 \pm 10.49 \\
130(120-140) \\
\end{array}$ & $\begin{array}{c}119 \pm 13.70 \\
120(110-130) \\
\end{array}$ & $0.015 *$ \\
\hline$-9 /+9$ & $\begin{array}{l}126.74 \pm 13.79 \\
120(120-135)\end{array}$ & $\begin{array}{l}125.64 \pm 14.93 \\
124(120-130)\end{array}$ & $\begin{array}{c}129.29 \pm 11.66 \\
130(120-140)\end{array}$ & 0.381 \\
\hline$+9 /+9$ & $\begin{array}{l}130.37 \pm 12.63 \\
130(120-140) \\
\end{array}$ & $\begin{array}{c}127.68 \pm 13.16 \\
130(120-130)\end{array}$ & $\begin{array}{c}128.48 \pm 10.28 \\
130(120-135) \\
\end{array}$ & 0.536 \\
\hline p value & 0.165 & 0.208 & 0.095 & \\
\hline $\begin{array}{c}\text { B2R } \\
\text { genotype }\end{array}$ & $\begin{array}{c}\text { DBP at third month } \\
\text { post-transplantation } \\
(\mathrm{mmHg}) \\
\end{array}$ & $\begin{array}{c}\text { DBP at sixth month } \\
\text { post-transplantation } \\
(\mathrm{mmHg}) \\
\end{array}$ & $\begin{array}{c}\text { DBP at twelfth month } \\
\text { post-transplantation } \\
(\mathrm{mmHg})\end{array}$ & $\begin{array}{c}\mathbf{p} \\
\text { value }\end{array}$ \\
\hline$-9 /-9$ & $\begin{array}{c}84.00 \pm 7.61 \\
80(80-90) \\
\end{array}$ & $\begin{array}{c}82.86 \pm 5.08 \\
80(80-85) \\
\end{array}$ & $\begin{array}{c}74.50 \pm 8.96 \\
75(70-80) \\
\end{array}$ & $0.020 *$ \\
\hline$-9 /+9$ & $\begin{array}{c}79.22 \pm 6.99 \\
80(75-80)\end{array}$ & $\begin{array}{l}78.05 \pm 8.31 \\
80(74.50-80)\end{array}$ & $\begin{array}{l}79.71 \pm 8.24 \\
80(75-85)\end{array}$ & 0.680 \\
\hline$+9 /+9$ & $\begin{array}{c}81.48 \pm 7.94 \\
80(80-85)\end{array}$ & $\begin{array}{c}80.36 \pm 8.38 \\
80(80-82.50)\end{array}$ & $\begin{array}{c}81.80 \pm 7.89 \\
80(80-90)\end{array}$ & 0.691 \\
\hline p value & 0.099 & 0.087 & 0.080 & \\
\hline
\end{tabular}

*significant difference; MAP-mean blood pressure; SBP-systolic blood pressure; DBP-diastolic blood pressure

Examination of the assumed interrelation between eGFR and blood pressure with respect to the B2R genotype is shown in Graph 1 . We differentiated blood pressure values to the target value in KTRs according to KDIGO (Kidney Disease: Improving Global Outcomes) working group (15). The recommended treatment goal is $\leq 130$ SBP and $\leq 80 \mathrm{DBP}$, irrespective of the level of urine albumin excretion. A rather strong correlation between hypertensive status and graft function was demonstrated, but only in carriers of both -9 alleles. Indeed, the -9/-9 genotype carriers with controlled blood pressure values had better graft function than patients with values beyond target $(61.11 \pm 18.03$
$\mathrm{mL} / \mathrm{min} / 1.73 \mathrm{~m}^{2}$ vs. $49.83 \pm 11.84 \mathrm{~mL} / \mathrm{min} / 1.73 \mathrm{~m}^{2}$, $\mathrm{p}=0.032)$. Such association was not found in carriers of $-9 /+9\left(45.22 \pm 14.39 \mathrm{~mL} / \mathrm{min} / 1.73 \mathrm{~m}^{2}\right.$ vs. $\left.43.74 \pm 12.64 \mathrm{~mL} / \mathrm{min} / 1.73 \mathrm{~m}^{2}, \mathrm{p}=0.559\right)$ and +9/+9 genotypes $\left(49.47 \pm 10.84 \mathrm{~mL} / \mathrm{min} / 1.73 \mathrm{~m}^{2}\right.$ vs. $\left.46.35 \pm 11.75 \mathrm{~mL} / \mathrm{min} / 1.73 \mathrm{~m}^{2}, \mathrm{p}=0.224\right)$. Regarding the most commonly prescribed antihypertensive regimens (i.e. beta blockers alone or in combination with calcium channel blockers), the difference in the frequency of used regimens between the different genotypes was not observed $\left(\chi^{2}=0.895\right.$, $p=0.639$ ) (Graph 2). 


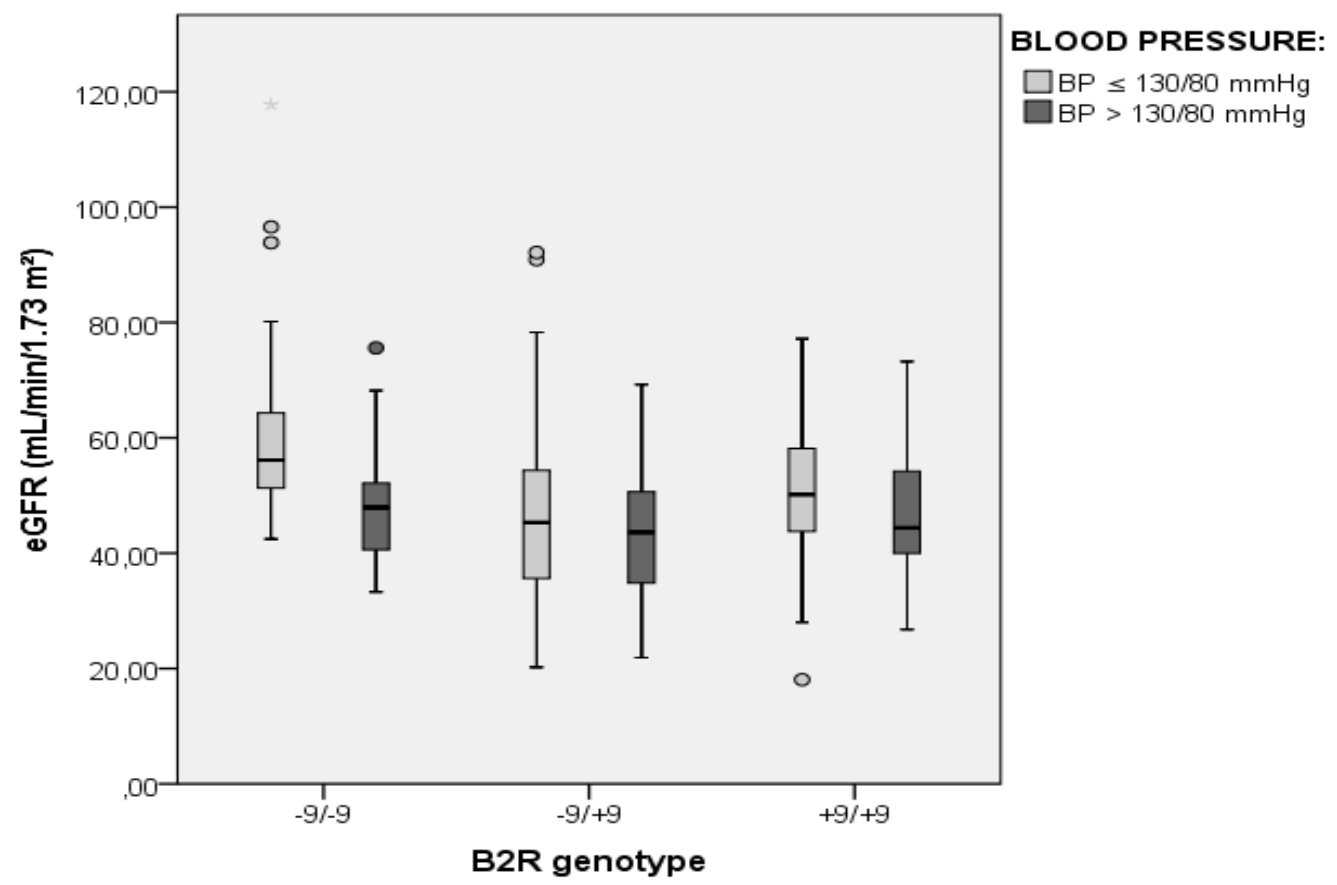

Graph 1. eGFR according to the target value of blood pressure in kidney transplant patients in relation to $B 2 R$ genotype

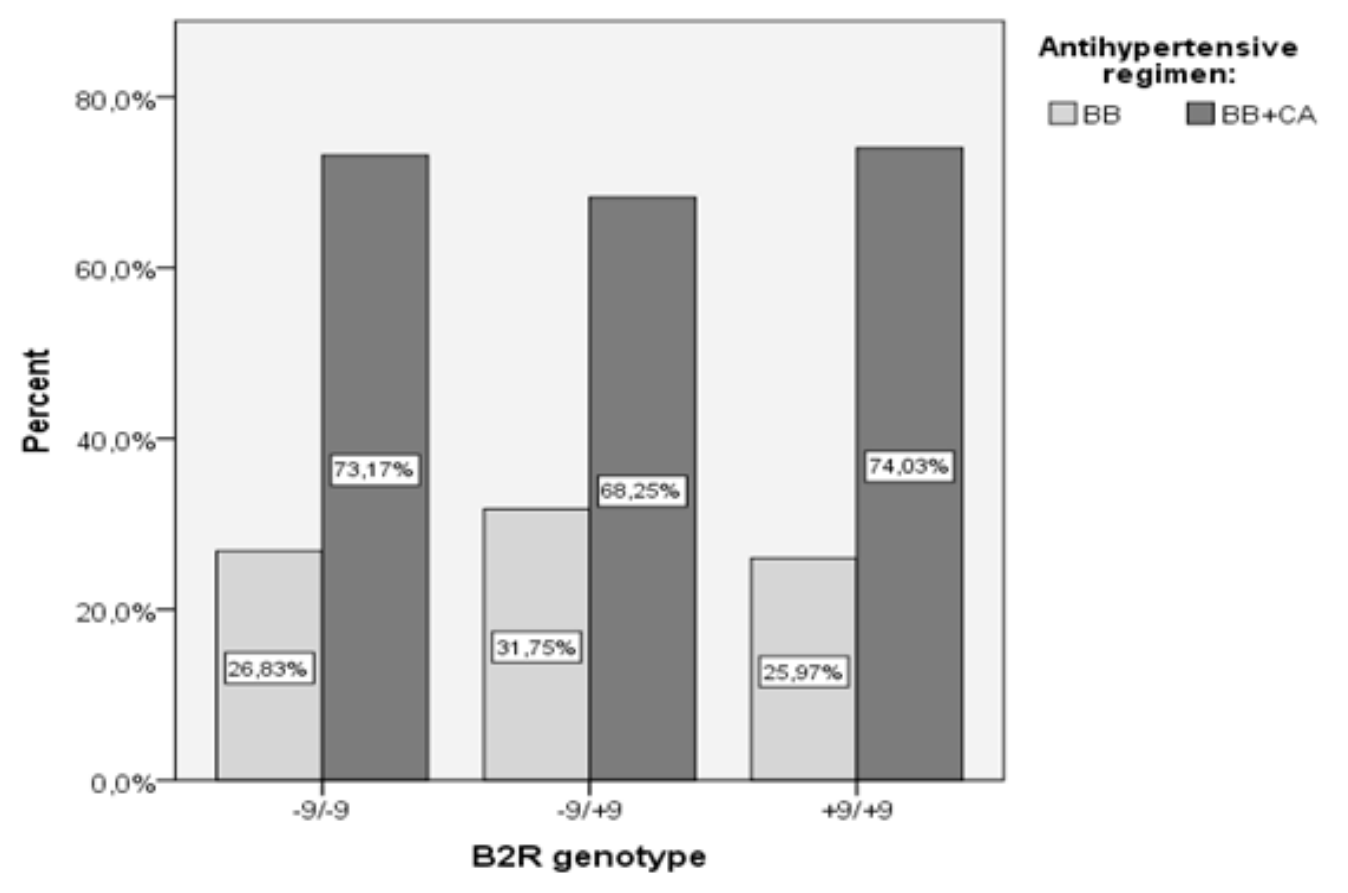

Graph 2. Frequencies of used antihypertensive regimens among B2R genotypes BB-beta blockers; CA-calcium channel blockers

\section{Discussion}

In the past few years, the KKS and its key mediator BK have been recognized as major con- tributors to endothelial vascular effects. The promotion of vasodilation is achieved through potentiation of nitric oxide (NO), prostacyclin, endothelium-derived hyperpolarizing factor synthesis and counter- 
action of the sympathetic nervous system. Besides crucial vasodilator action, BK exerts antithrombotic, profibrinolytic, and anti-atherosclerotic effects, as well as protective activity against endothelial injury (16). Namely, BK acts primarily as tissue hormone, since the half-life of BK in plasma is very short (27 \pm $10 \mathrm{~s})$ (17) along with very low circulating concentrations (1-50 fmol/mL). In accordance with paracrine hormonal activity, tissue concentrations are considerably higher, especially in cardiac and renal tissue (100-350 fmol/g) (5).

The balance between afferent and efferent arteriole resistance is important for the regulation of glomerular filtration rate. Ren et al. (18) demonstrated a biphasic effect of BK on the isolated afferent arteriole (i.e. vasodilation at low concentrations and vasoconstriction at higher concentrations), and a dose-dependent vasodilator action on the efferent arteriole. These findings support the comprehensive BK effect on glomerular hemodynamics through B2R. Contrary to the generally accepted fact that the promotion of vasodilatation is NO-dependent, the authors showed that vasodilator action on efferent arteriole was mediated by CYP450 metabolites (probably epoxyeicosatrienoic acids, EETs), and it was NO- and cyclooxygenase-independent.

Considering the B2R-mediated BK effects, our study confirmed that the $9 \mathrm{bp}$ insertion/deletion variability in the gene encoding B2R may significantly affect the vasoprotective effects of BK. The obtained difference in graft function between B2R genotypes at all observed time-points may indicate the potential renoprotective role of the preserved BK-B2R signaling in -9/-9 genotype carriers. Of particular importance is the existence of a significant difference in eGFR values at the end of the first year, keeping in mind that kidney allograft function at 1year was shown to be independently associated with long-term adverse outcomes (19, 20). The correlation of this polymorphism with the kidney pathology was previously observed in an experimental streptozotocin-induced diabetic model. The authors noticed numerous pathological alterations in renal tissue within B2R insertion polymorphism, such as glomerular lesions, extracellular matrix accumulation, thickening of the glomerular basement membrane, and oxidative damage. Additionally, metabolic disorders, altered inflammatory response, and mitochondria dysfunction have contributed to the further progression of diabetic nephropathy (21). Therefore, it seems that genetic factors along with the nature of the kidney disease may contribute to the modulation of the vascular protective effects of BK.

Renal tissue kallikrein (TK) is mainly sited in the principal cells of the distal connecting tubules and the collecting ducts, and it acts on renal kininogen to form kinins either in the interstitial tissue space or in the lumen of the distal nephron and collecting ducts. Since the connecting tubules are localized close to the glomerular tuft, the effect of released $\mathrm{BK}$ on afferent and efferent arteriole can be one of the proposed ways for a kinins-induced increase in renal blood flow $(18,22)$. Studies have demonstrated a significantly lower urinary excretion of TK into the lumen of the distal nephron in KTRs with hypertension and acute renal complications. Nevertheless, diminished excretion was also characteristic of KTRs with a stable graft function $(23,24)$. Namely, the assumed lower B2R expression in carriers of +9 allele and previously reported decrease in kinin formation due to diminished TK excretion in patients with a transplanted kidney could potentially explain the results of the present study. Besides the reported lower urinary excretion of TK in KTRs compared with healthy individuals, Amorim et al. (25) demonstrated a higher frequency of +9 allele in transplanted patients ( +9 allele: $55 \%,-9$ allele: $45 \%$ ) than in control individuals ( +9 allele: $48 \%$, -9 allele: 52\%) (25). Regarding the allelic frequencies for the B2R variants, different frequencies in various ethnic groups were reported (Caucasian Polish: +9-51\%, -9-49\%; Caucasian British: +948\%, -9-52\%; White American: $+9-50 \%$, -9-50\%; Black American: $+9-40 \%$, $-9-60 \%)(26,27,28)$. The results of the present study are in agreement with Amorim's findings (25) since the frequency of +9 and -9 allele in KTRs was $57.37 \%$ and $42.63 \%$, respectively. Contrary to our study, the authors did not confirm the association between B2R polymorphism and the high mean serum creatinine level. A possible explanation for this divergence may be the use of different estimates of kidney function.

Namely, serum creatinine level alone is not considered as an adequate marker of kidney function, while the level of eGFR and its magnitude of change represent the best overall index for the detection of kidney disease and estimation of its severity and prognosis.

Hypertension is one of the major risk factors for cardiovascular disease after Tx. Kasiske et al. (29) showed that blood pressure at 1-year posttransplantation was negatively associated with graft and patient survival. The findings of the conducted study reported a noticeable pressure reduction at the $12^{\text {th }}$ month in $-9 /-9$ genotype carriers. Our results can be partly explained by the study of Pretorius et al. (28), which pointed to increased baseline SBP and MAP in carriers of +9 allele compared to the carriers of $-9 /-9$ genotype in healthy adults, while B2R polymorphism did not influence the vasodilator response to exogenous BK. However, in the presence of ACE inhibitor enalaprilat, BKstimulated vasodilation was significantly potentiated, with the effect being more pronounced in carriers of $-9 /-9$ and $-9 /+9$ genotypes compared to the $+9 /+9$ genotype carriers (30). Furthermore, increased SBP was significantly associated with increased coronary event risk in carriers of $+9 /+9$ and $-9 /+9$ genotypes, whereas the significant association was not observed among -9/-9 genotype carriers (31). Our data gave an insight into another important correlation, i.e. rather strong interrelation between hypertensive status and graft function in the first year after Tx, but only in the $-9 /-9$ genotype patient group.

Analyzing antihypertensive therapy, the most prescribed regimens in the present study were beta blockers in monotherapy (25\% of all patient's examinations) and beta blockers in combination with calcium channel blockers (60\% of all patient's examinations). Since the results did not show the dif- 
ference in the distribution of antihypertensive regimens between B2R genotypes, the possible conclusion would be that the blood pressure parameters were not influenced by the used antihypertensive therapy. Consequently, this points to the fact that the hypertensive status was largely affected by the B2R genotype. We did not consider patients on ACE inhibitors due to a small number of patients using them and cross-talk between the renin-angiotensin system and the KKS. Therefore, the carriers of +9 allele may potentially benefit from the introduction of ACE inhibitors into the therapy, because ACE inhibitors are the most effective drugs nowadays in enhancing the KKS through reducing the degradation of endogenous $\mathrm{BK}$ and enhancing the sensitivity of the $\operatorname{B2R}(4,30)$.

Some limitations of the study need to be mentioned. The first drawback of the present research was a small number of patients, and therefore a small number of patients per genotype group, but still this is a single-center study. The second drawback was a short follow-up period. However, graft function and blood pressure at 1 year after Tx were shown to be associated with long-term adverse outcomes, so this study could be the basis for further researches.

\section{Conclusion}

In conclusion, this study indicated the potential effect of $B 2 R+9 /-9$ polymorphism on the stability of kidney function and blood pressure control in transplanted patients. Namely, the carriers of -9/-9 genotype exhibited more stable graft function and blood pressure levels at the end of the first year following Tx compared to the carriers of +9 allele. The carriers of +9 allele may benefit from the introduction of ACE inhibitors into the therapy in order to overcome the reduced kinins formation and lower B2R expression. Therefore, genotyping of this polymorphism alongside with biochemical and clinical parameters may identify patients with regard to the risk of more prompt decline of graft function. However, further studies with a longer follow-up period are needed to examine the effects of B2R polymorphism on long-term Tx outcomes alongside the assessment of interdependence between hypertensive status and graft function.

\section{Acknowledgments}

This study was supported by the Ministry of Education, Science and Technological Development of Serbia-project number III 41018.
1. Chapman JR. What are the key challenges we face in kidney transplantation today? Transplant Res 2013; 2(Suppl 1):S1. [CrossRef] [PubMed]

2. Kidney Disease: Improving Global Outcomes (KDIGO) Transplant Work Group. KDIGO clinical practice guideline for the care of kidney transplant recipients. Am J Transplant 2009;9(Suppl 3):S1-S157. [CrossRef]
3. Djamali A, Samaniego $M$, Muth $B$, Muehrer $R$, Hofmann RM, Pirsch J, et al. Medical care of kidney transplant recipients after the first posttransplant year. Clin J Am Soc Nephrol 2006;1(4):623-40. [CrossRef] [PubMed] 
4. Kakoki M, Smithies O. The kallikrein-kinin system in health and in diseases of the kidney. Kidney Int 2009; 75(10):1019-30. [CrossRef] [PubMed]

5. Rhaleb NE, Yang XP, Carretero OA. The kallikrein-kinin system as a regulator of cardiovascular and renal function. Compr Physiol 2011;1(2):971-93.

[CrossRef] [PubMed]

6. Golias $\mathrm{CH}$, Charalabopoulos A, Stagikas D, Charalabopoulos K, Batistatou A. The kinin system-bradykinin: biological effects and clinical implications. Multiple role of the kinin system-bradykinin. Hippokratia 2007;11(3):124-8. [PubMed]

7. Manolis AJ, Marketou ME, Gavras I, Gavras H. Cardioprotective properties of bradykinin: role of the B(2) receptor. Hypertens Res 2010;33(8):772-7. [CrossRef] [PubMed]

8. Sharma JN, Al-Banoon A. The Role of Inflammatory Mediator Bradykinin in Cardiovascular and Renal Diseases. Sci Rep 2012;1(2):142.

9. Bhupatiraju C, Patkar S, Pandharpurkar D, Joshi S, Tirunilai P. Association and interaction of $-58 \mathrm{C}>\mathrm{T}$ and \pm 9 bp polymorphisms of BDKRB2 gene causing susceptibility to essential hypertension. Clin Exp Hypertens 2012;34(3):230-5. [CrossRef] [PubMed]

10. Alvim Rde O, Santos PC, Nascimento RM, Coelho GL, Mill JG, Krieger JE, et al. BDKRB2 +9/-9 Polymorphism is associated with higher risk for diabetes mellitus in the Brazilian general population. Exp Diabetes Res 2012;2012:480251. [CrossRef] [PubMed]

11. Halimi JM, Persu A, Sarafidis PA, Burnier M, Abramowicz D, Sautenet B, et al. Optimizing hypertension management in renal transplantation: a call to action. Nephrol Dial Transplant 2017;32(12):1959-62. [CrossRef] [PubMed]

12. Aziz F, Clark D, Garg N, Mandelbrot D, Djamali A. Hypertension guidelines: How do they apply to kidney transplant recipients. Transplant Rev (Orlando) 2018; 32(4):225-33. [CrossRef] [PubMed]

13. Levey AS, Coresh J, Greene T, Stevens LA, Zhang YL, Hendriksen $S$, et al. Using standardized serum creatinine values in the modification of diet in renal disease study equation for estimating glomerular filtration rate. Ann Intern Med 2006;145(4):247-54. [CrossRef] [PubMed]

14. Fischer $M$, Lieb W, Marold D, Berthold M, Baessler A, Lowel $\mathrm{H}$, et al. Lack of association of a 9 bp insertion/deletion polymorphism within the bradykinin 2 receptor gene with myocardial infarction. Clin Sci (Lond) 2004;107(5):505-11. [CrossRef] [PubMed]

15. Kidney Disease: Improving Global Outcomes (KDIGO) Blood Pressure Work Group. KDIGO Clinical Practice Guideline for the Management of Blood Pressure in Chronic Kidney Disease. Kidney inter Suppl 2012;2: 337-414.

16. Regoli D, Gobeil F Jr. Critical insights into the beneficial and protective actions of the kallikrein-kinin system. Vascul Pharmacol 2015;64:1-10. [CrossRef] [PubMed]

17. Cyr M, Lepage $Y$, Blais C Jr, Gervais N, Cugno M, Rouleau JL, et al. Bradykinin and des-Arg(9)-bradykinin metabolic pathways and kinetics of activation of human plasma. Am J Physiol Heart Circ Physiol 2001; 281(1):H275-83. [CrossRef] [PubMed]

18. Ren Y, Garvin J, Carretero OA. Mechanism involved in bradykinin-induced efferent arteriole dilation. Kidney Int 2002;62(2):544-9. [CrossRef] [PubMed]
19. Hariharan S, McBride MA, Cherikh WS, Tolleris CB, Bresnahan BA, Johnson CP. Post-transplant renal function in the first year predicts long-term kidney transplant survival. Kidney Int 2002;62(1):311-8. [CrossRef] [PubMed]

20. Lenihan CR, O'Kelly P, Mohan P, Little D, Walshe JJ, Kieran NE, et al. MDRD-estimated GFR at one year post-renal transplant is a predictor of long-term graft function. Ren Fail 2008;30(4):345-52.

[CrossRef] [PubMed]

21. Zou H, Wu G, Lv J, Xu G. Relationship of angiotensin I-converting enzyme (ACE) and bradykinin B2 receptor (BDKRB2) polymorphism with diabetic nephropathy. Biochim Biophys Acta Mol Basis Dis 2017; 1863(6):1264-72. [CrossRef] [PubMed]

22. Ramsaroop R, Naicker S, Naicker T, Naidoo S, Bhoola KD. Tissue kallikrein in transplant kidney. Immunopharmacology 1997;36(2-3):255-61. [CrossRef][PubMed]

23. Spragg J, Denney DL, Tilney NL, Frank Austen K. Kallikrein excretion in renal transplant recipients and in uninephrectomized donors. Kidney Int 1985;28(1): 75-81. [CrossRef] [PubMed]

24. O'Connor DT, Barg AP, Amend W, Vincenti F. Urinary kallikrein excretion after renal transplantation: relationship to hypertension, graft source, and renal function. Am J Med 1982;73(4):475-81. [CrossRef] [PubMed]

25. Amorim CE, Nogueira E, Almeida SS, Gomes PP, Bacurau RF, Ozaki KS, et al. Clinical impact of an angiotensin I-converting enzyme insertion/deletion and kinin B2 receptor $+9 /-9$ polymorphisms in the prognosis of renal transplantation. Biol Chem 2013; 394(3):369-77. [CrossRef] [PubMed]

26. Grenda A, Leońska-Duniec A, Cięszczyk P, Zmijewski P. Bdkrb2 gene $-9 /+9$ polymorphism and swimming performance. Biol Sport 2014;31(2):109-13. [CrossRef] [PubMed]

27. Williams AG, Dhamrait SS, Wootton PT, Day SH, Hawe E, Payne JR, et al. Bradykinin receptor gene variant and human physical performance. J Appl Physiol (1985) 2004;96(3):938-42. [CrossRef] [PubMed]

28. Pretorius MM, Gainer JV, Van Guilder GP, Coelho EB, Luther JM, Fong $P$, et al. The bradykinin type 2 receptor $\mathrm{BE} 1$ polymorphism and ethnicity influence systolic blood pressure and vascular resistance. Clin Pharmacol Ther 2008;83(1):122-9. [CrossRef] [PubMed]

29. Kasiske BL, Anjum S, Shah R, Skogen J, Kandaswamy C, Danielson B, et al. Hypertension after kidney transplantation. Am J Kidney Dis 2004;43(6):107181. [CrossRef] [PubMed]

30. Van Guilder GP, Pretorius M, Luther JM, Byrd JB, Hill $\mathrm{K}$, Gainer JV, et al. Bradykinin type 2 receptor BE1 genotype influences bradykinin-dependent vasodilation during angiotensin-converting enzyme inhibition. Hypertension 2008;51(2):454-9. [CrossRef] [PubMed]

31. Dhamrait SS, Payne JR, Li P, Jones A, Toor IS, Cooper $J A$, et al. Variation in bradykinin receptor genes increases the cardiovascular risk associated with hypertension. Eur Heart J 2003;24(18):1672-80. [CrossRef] [PubMed] 


\title{
POTENCIJALNI ZNAČAJ GENOTIPIZACIJE POLIMORFIZMA BRADIKININ TIP 2 RECEPTORA KOD BOLESNIKA SA TRANSPLANTIRANIM BUBREGOM
}

\author{
Katarina Danković ${ }^{1}$, Nikola Stefanović1, Radmila Veličković-Radovanović1,2, \\ Branka Mitić1,2, Goran Paunović ${ }^{2}$, Mina Cvetković1,2, Tatjana Cvetković1,3
}

\author{
${ }^{1}$ Univerzitet u Nišu, Medicinski fakultet, Niš, Srbija \\ ${ }^{2}$ Klinički centar Niš, Klinika za nefrologiju, Niš, Srbija \\ ${ }^{3}$ Klinički centar Niš, Centar za medicinsku i kliničku biohemiju, Niš, Srbija
}

Kontakt: Nikola Stefanović

Bulevar dr Zorana Đinđića 48, 18000 Niš, Srbija

E-mail: nikola.stefanovic@medfak.ni.ac.rs

Bradikinin (BK), vazoaktivni peptid, ispoljava renoprotektivne i kardioprotektivne efekte. Osim toga, većina njegovih efekata posredovana je aktiviranjem BK tip 2 receptora $(B 2 R)$, na čiji nivo ekspresije utiče genski polimorfizam insercije/delecije 9 baznih parova $(+9 /-9)$.

Cilj ovog istraživanja bila je procena potencijalnog uticaja B2R +9/-9 genskog polimorfizma na funkciju grafta i krvni pritisak kod bolesnika sa transplantiranim bubregom, tokom prve posttransplantacione godine. Takođe, $\mathrm{u}$ ovoj studiji analizirana je povezanost hipertenzivnog statusa i funkcije grafta u odnosu na B2R $+9 /-9$ polimorfizam.

$\mathrm{U}$ farmakogenetsko istraživanje uključeno je 95 bolesnika sa transplantiranim bubregom, čiji su klinički i biohemijski parametri analizirani u tri vremenske tačke $(3 ., 6$. i 12. meseca). Funkcija grafta proračunata je korišćenjem procenjene brzine glomerularne filtracije (eGFR), dok su sistolni (SBP), dijastolni (DBP) i srednji krvni pritisak (MAP) korišćeni kao parametri za evaluaciju kontrole krvnog pritiska.

Nosioci $-9 /-9$ genotipa imali su stabilniju funkciju grafta u poređenju sa heterozigotima i homozigotima za +9 alel, ne samo u ranom (do 6 meseci), već i u kasnom periodu nakon transplantacije bubrega (nakon 6 meseci). Takođe, nosioci $-9 /-9$ genotipa pokazali su tendenciju značajnog smanjenja MAP, SBP i DBP u posmatranom periodu, pri čemu je samo u ovoj grupi bolesnika pokazana statistički značajna povezanost hipertenzivnog statusa i funkcije grafta.

Genotipizacija B2R +9/-9 genskog polimorfizma, zajedno sa biohemijskim i kliničkim parametrima, može identifikovati bolesnike prema riziku od bržeg propadanje funkcije transplantata.

Acta Medica Medianae 2021;60(1):19-27.

Ključne reči: $B 2 R$ polimorfizam, transplantacija bubrega, krvni pritisak, funkcija grafta, antihipertenzivna terapija 